\title{
Make Women Great Again: Women, misogyny and anti-capitalism on the right
}

\author{
Caherine Tebaldi
}

\section{Intoducion}

Neo-confederate blogger Dissident Mama describes the January 6 Capitol Insurrection as "\#resistance without the corporate sponsorship". In a series of blogs, she appropriates the language of anti-capitalist movements to defend armed resistance from Charlottesville to the Capitol. Negative media coverage is woke "agitprop" by elites: journalists and politicians, but also "corporate goons." These politicians, meanwhile, are the "very people who are empowered and enriched by mass democracy, forever wars, and our oppression1", according to Mama. The language of wealth, profit, and enrichment is used to criticize liberal democracy as in the throes of corporations and imperial wars. However, liberalism's chief attack is on the family and the forgotten man, and for Momma, its shock troops are the feminists.

Defending the Capitol riots, Dissident Momma positions herself, a stay-at-home mother, as at the front lines of another kind of insurrection. She is uniquely capable of speaking out against the tyranny of woke capital, political correctness and corporate HR's liberal cancel culture. Without a boss, she cannot be fired or cancelled for expressing explicit racism. Secondly, a stay-at-home mother is the guardian of traditional morality, family values, and southern White identities which are being attacked by the corporate cultural Marxists. The home has become the new battleground, as Mama herself points out.

Her own insurrection is homeschooling. Post after post, Dissident Mama compares the act of homeschooling to the civil war; it is "educational secession" freeing her children from the "puritanical progressives" or the Northern "power elite" who run the state and public schools and seek to impose a "globohomo tyranny" on Southern boys. She echoes familiar moral panics over cultural Marxism, describing teachers as "apparatchiks" and schools as a "gulag of the mind." But when she discusses the supposed anti-white bias of "the educrats" who want to make children "rootless, hopeless, and disoriented" she uses the language of anti-capitalism; despite being marxists they want to make children "loyal consumers of both the corporate and governmental systems"2

For Mama the opposition of corporate cultural marxism is raising children in their "heritage" of southern-style White supremacy. She believes in the lost cause mythology which celebrates the antebellum South as the high-water mark of western civilization, and frames today's White Southerners as an oppressed "remnant." Mama uses the language of anti-capitalism, but she supports not socialism but paleolibertarianism. Paleolibertarians support deep social conservatism (or sexism and racism) along with economic libertarianism, a belief system with roots in chattel slavery (Maclean 2017). Capitalism is good when it supports homeschooling and heritage; her blog is an Amazon affiliate and advertises for Ron Paul's libertarian homeschooling, the Tuttle Twins libertarian children's fables, in addition to the white nationalist Christendom Curriculum. 
Anti-capitalist language shades quickly into anti-feminism, in Dissident Mama's discourses, dismissing social change as HR newspeak and conflating postwar gender roles with postwar affluence. Sophie Bjork James (2020) notes that the Christian right often blames feminism for the socio-economic struggles of late capitalism. This is something common across the far-right: Identitarian Lacey Lynn calls feminism elitist and anti-working class, conspiratorial vlog and radio station RedIce positions fascist women at the front lines in the fight against corporate communism, while the evolutionary psychologists of the intellectual dark web from Stefan Molyneux to Jordan Peterson use the language of corporate anomie to argue for gender essentialism.

Anti-capitalist language is deployed against working women while elevating White working men, providing a return to "traditional" roles as an answer to economic as well as social challenges. That is, right wing language displaces anxieties about capitalism onto anxieties about gender roles, family and love. In this essay I look at women in far-right activism, and the ways in which anti-capitalist language is used to celebrate the gender roles of post-war American breadwinner capitalism. This at once diminishes feminist and socialist critques, enougaging the reframing of economic concerns into what Rosenthal (2020) calls gendered dispossession. This emerges from real failures of liberal feminism and late capitalism, but appropriates critiques of capital that might challenge the identity politics of the white right, instead encouraging reinvestment in the conservative social order.

\section{Anti-Capital/Anti-Gender}

How is it that the language of anti-capitalism can be used to support the party of oligarchs and oil? As Stuart Hall notes, gender has long served as a way to mobilize contradictory tendencies between capitalism and traditionalism on the right. For Hall (1988), the contradictions between traditionalist values and market capitalism were resolved by mapping these onto the gendered public and private spheres. Women became symbols of the home, morality, and tradition, while men became engaged in competition for the survival of the fittest. The neoliberalization of work life was accompanied by an intense discursive investment in family, timeless morality, and wisdom.

Women in the home became symbols of atavistic tradition, both popular morality and wisdom. Women working, or on welfare, have become in the contemporary right, symbols of all the ills that the liberal social order has inflicted on man, tradition, and the family. This vision of the 1950's, of postwar economic order, the ease of a life with a social safety net and subsidized mortgages, will be used on the far-right to represent suburban affluence through the metonym of "traditional gender roles." Using stay-at-home mothers to portray lost affluence encourages a moral panic about gender roles, rather than capital.

Kovats and Poim (2018) note the importance of antifeminism for right wing organizing. They describe gender as a "symbolic glue"; gender has become a symbol for all the unfairness experienced in the neoliberal social order, from economic deprivation to social isolation or a loss of male supremacism. Uniting multiple elements of neoliberalism under the umbrella term "gender ideology," this symbolic opponent also allows different right-wing groups to come together. Gender may function as Kovats and Poim's symbolic glue, but it also becomes a site of slippage between economic and social interpretations of crisis.

Gender ideology doesn't merely unite these critiques of neoliberalism, but becomes a fetish object (Inoue 2004) which replaces them. From moral panics over welfare queens or satanic day cares the family, women, and motherhood were often mobilized both practically and symbolically for rightist political economy. In the gilded age Bederman (1995) notes how, as opportunities for land ownership and social mobility became restricted, affectively changed visions of masculinity as the virile domination of women replaced older visions of manhood as self-control. As the empire grew, patriarchal roles were used to justify imperialism, framing America as the husband of its colonies, and celebrating war as producing strong American fathers (Hoganson 1998). In the postwar era, Cooper (2016) explains how conservative social values were enforced by the neoliberal erosion of the welfare state, which forced the family to become the locus of social care, while at the same time the celebration of "family values" provided a moral pretext for dismantling the welfare state. During deindustrialization, gendered dominance was used to win men's consent to the right wing order as economic options become restricted, now mobilizing women and housewives as to reject 
feminism and, with help from sex manuals by women like Marabel Morgan and Beverly La Haye, to use sexualized submission to shore up manliness (DuMez 2020). The affective investment in masculinity and virility grew in value as economic opportunity shrank, and after the 1970's women took a larger and more active role in shoring up and reproducing male supremacism. From Schalfly to sex kittens, women were encouraged to see their role in the home as a choice, a privilege, and then as a battleground in the culture war. Today, far-right women extend this - positioning their role in the home as the culture war's front line.

Returning to Stuart Hall (1988), in moments of social crisis dominant ideology must appropriate experiences of economic crisis, and express them in ways that continue to support ruling power. While personal experiences of the social crises of capitalism are influenced by how dominant ideology is taken up, this is always partial. Dominant ideology must continually offer new propagandas, moral panics to win the consent of the governed. Even the right is beginning to notice capitalism isn’t providing sufficient ROI.

Contemporary far-right politics, then, has to mobilize gender roles in new ways in order to continue to win consent to the capitalist social order, and to continue to provide affective visions of masculinity and femininity. As the labor market conditions and opportunities rapidly worsen, and gender becomes more fluid, far-right discourses must become more intense. Far right metapolitics now mobilize anti-feminism as a deep critique of liberalism; they seek to re-gender both capital and re-gender the public sphere more broadly. To win consent to a worsening crisis, this discourse must move further right, and in doing so there are two main changes. First, a larger role for women within these movements, and with these housewife insurrectionists, a greater importance for both anti-feminist ideology and anti-capitalist language.

\section{Organizing women}

As Dissident Mama notes, women are soldiers at the front line of right wing organizing; sometimes entering electoral politics as Marjorie Taylor Greene did, sometimes storming the Capitol, but more often spreading the message through mommy blogs, church groups, or the "pastel Qanon" of instagram wellness communities. Women's role in home and family is reframed as combat, promoting a renewed affective investment in this "traditional" role, while framing white heteropatriarchy as "family values" (see Bjork James 2021) normalizes their broader political aims.

Women have been part of both the far right (Blee 2012) and movement conservatism; their involvement and often leveraged their identity as mothers, from "housewife populists" (Nickerson 2012) fighting school integration, to Schlafly's "femininity tactics" which involved well coiffed anti-ERA women who offered homemade bread to male politicians with the line "from the bread bakers to the breadwinners." Today however, their role is larger; a majority of organizers in the Tea Party are women (Westermeyer 2019), while 55 percent of Christian Nationalists, one of the main ideologies behind support for Trump and the Capitol insurrection, are women (Whitehead \& Perry 2020).

Antifeminist women are central for the digital far-right as well. Women play a similar role of recruitment and retention online as Blee (2002) noted women do in earlier, offline, white nationalist movements. Tradwives, the female members of far-right groups who advocate "traditional" gender roles, also build community, attract and retain new members, and conduct outreach. They create channels and networks like Critical Condition's "Girl Talk" which brings together women from various strands of the right from the Identitarian Cheerleader Blonde in the Belly of the Beast to Neo-Pagan Fascist Philosophicat. Dissident Mama, for example, brings together Paul Gottfried, the man who coined the term Alt-Right, the leader of the NeoConfederates, with housewives and small business owners protesting lockdown. Their idealized performances of midcentury femininity may also attract members from men's rights and other groups, "red pill" men, or convince some men to remain in this online community. And of course, they educate online and homeschool children.

Many far-right women frame this "traditional" role as their own insurrection. In her video "Community: the traditional woman's battle ground” Lacey Lynn notes that women's traditional roles were to support and build 
community, but she describes this as a battle ground, against the forces of feminism and big pharma. First, because "femininity, motherhood and the family" are under attack from feminism, the traditional woman is introduced as having a "place in the fight for the future of her children" by building a family and a community. In other videos Lynn calls herself a momma bear, a warrior for her kids. Similarly, Lana Lokteff refers to herself as a "viking shield maiden" in the war for a white west, likening her role in the battle for white nationalism to a viking woman picking up a shield to defend her home. Women's economic participation is the sign of this decadence, but this decadence is also what allows Lokteff and others to take a place in the front lines of the fight.

Far right women rhetorically imagine their decision to stay home as a fight against soulless corporations that steal mothers from families, to save tradition, love and domestic bliss. The far-right has a long tradition of using domesticity and white femininity to normalize their politics, to reframe racism as moral appropriateness or family values (Bjork James 2021, Butler 2021). This alt-maternalism (Mattheis 2018) also gives a sense of urgency and rebellion to the choice to be a stay at home mother, deepening engagement with this role that is already central to many women's lives. For many women (including my own mom) right offers a broader and more activist definition of motherhood promoting women's affective engagement with these politics. They can then mobilize this division between capital and community for organizing.

Celebrating traditionalist women allows the right to demonize feminists. If traditional women represent the solution to all of the problems of late capitalism, the return to harmony and happy mother nature, feminists come to represent all of the failures of the neoliberal political, social, and economic order. This "symbolic glue" allows the right to locate roots of male oppression in feminism, not capitalism, to see the economic and social loss of the breadwinner role in purely gendered terms. This anti-feminism can absorb critiques of capitalism's sickness, encouraging others to see the prescription as farther right, White or Christian nationalist positions.

\section{Moms Not Worker Drones}

Right wing discourse displaces the anxieties and unease of capitalism onto anxieties about women's changing role in the family. Feminism is described as unfulfilling and unnatural, as corporate anomie and HR newspeak, as elite cultural Marxism and anti working men, as weakening the family and community. With the exception of cultural Marxism, all of these things are true of corporate capitalism, but these discourses ascribe it to liberal feminism. This is done both explicitly, through discussions of women's nature, and implicitly, by connecting these critiques of capital primarily to women.

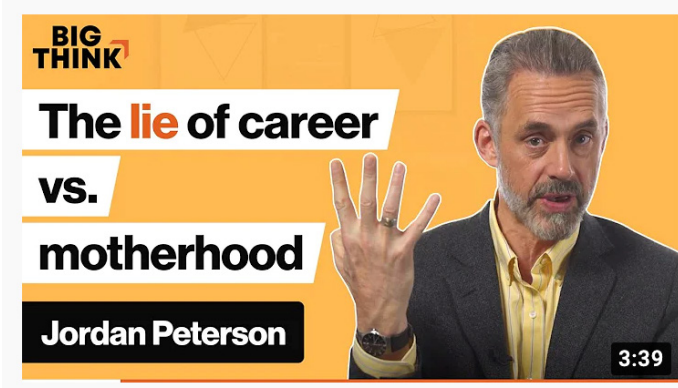

Figure 1. Jordan Peterson's pseudo-academic videos celebrating motherhood as women's meaning.
This exists on a spectrum across the right, beginning with the quite reactionary but widely read Jordan Peterson - in mainstream, academic looking videos. Peterson describes his role counseling an indeterminate number of late 30s women who feel unfulfilled by their jobs. He says corporate America "fed us a lie" and told us our careers were fulfilling, alienated us from fundamental humanity, meaning, purpose, and community. As we see in a representative video below,

Peterson begins by critiquing the late capitalist obsession with career, pointing out the ways the current economy makes most people work unfulfilling jobs and those who do have careers often sacrifice personal life. Yet the lie he says our culture tells is not in fact, exploitation, but the lack of celebration of motherhood. He calls this "the good-mother archetype." The difficulties of work life balance serve to normalize his baldly anti-feminist claim that all women who are not mentally ill desire motherhood over career at 30, and are desperate for children by 40. Of course, Peterson himself does not experience his career as a lack of fulfillment, alienation, or being a soulless corporate shill. This opposition of career and motherhood, rather than parenting, excludes any male patients, instead, the critique of corporate employment is female, and the alternative is a return to babies and baking. 
A bit further on the pseudo-philosophical, misogynist right, Stefan Molyneux picks up where Peterson left off. Molyneux begins with a discussion of the second shift that working women engage in, the stress of late capitalist life and the lack of time for with a family as anathema to the "personal fulfillment" described by the original poster. Again, working long hours and maintaining a family is an issue, but this language is aimed only at women. There is no discussion of dad's lack of time to play soccer with the kids, or do household chores and cooking, in any of his videos.

In tweets, figures 2 and 3 below, we see how concern about working a second shift at home really means concern about women working at all.

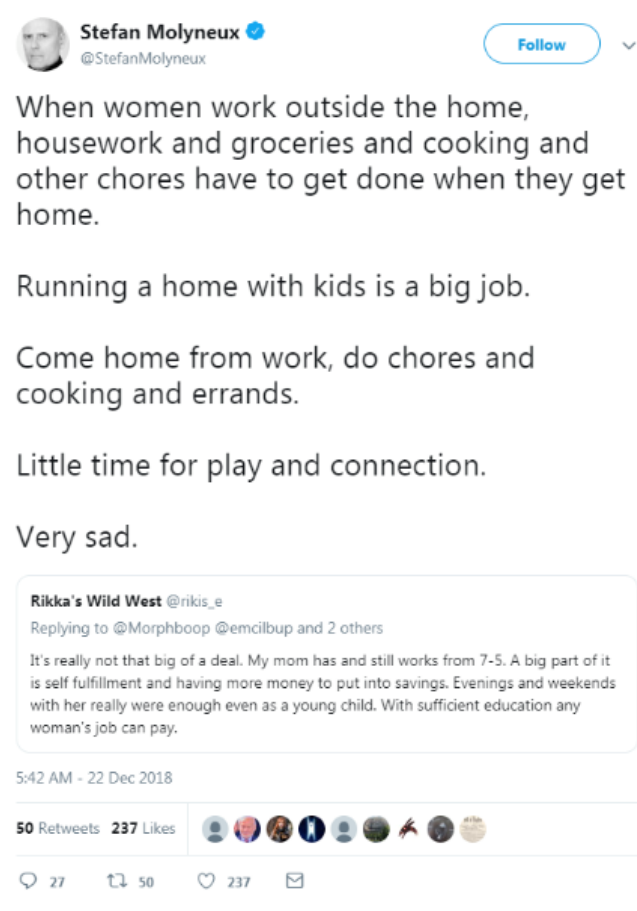

Figure 2. Stefan Molyneux's tweet about the struggles of working women

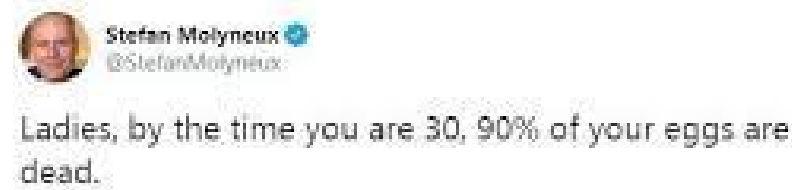

dead.

Get married young, have your babies, THEN have your career.

You have 40 years to work if you want to, you only have a short time to have children.

Listen to Mother Nature - she loves you and wants you to be happy. :)

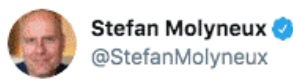

Women get mostly infertile at 40 , but live to be 80 .

\section{Without a family, what are you going to do with those 40 long long years?}

Figure 3. Two more of Molyneux's tweets clarifying he supports motherhood, not better working conditions for women.

That this is not merely a coincidence or the deployment of family against capitalism is made clear by other of Molyneux's tweets; the lack of purpose and fulfillment is because women are designed by nature to bear children. In the two tweets below Molyneux discusses women's fertility in opposition to careers.

In the first, he makes it clear that career is bad because it gets in the way of having children early; capitalist success is opposed to "Mother Nature." Nature and happiness, however, is treated as the same thing as bearing children. In the next tweet, this is made even clearer, as childless women are relegated to 40 years of lonely meaningless life. Nature here, means fertility, family, biological "facts" about eggs naturalizing a postwar gender role. Capitalism then, is wrong and meaningless when it is opposed to nature and joy. But for Molyneux, nature means our role as incubators for white babies. Molyneux affirms this when he speaks at the 21 convention, a grassroots organizing event for the worldwide manosphere (anti-feminist) community. His speech is called "Make women great again."

This fight for motherhood not worker drones is not just fought by the men of the Intellectual Dark Web, but by a growing number of far-right female activists. Most invested in this type of anti-feminist/capitalist language are the tradwives, a group of women in their 20s -40s, who celebrate "traditional gender roles" including women staying at home, homeschooling, and submitting to their husbands. Mainstream media often frame this return in anti-capitalist terms, as in figure 4 below, a video framing homemaking as freedom from employers. 
Online they echo these talking points, sharing memes that submitting to one husband is better than submitting to 10 bosses, or making videos about how much happier they are as they gave up lonely careers in finance to marry true masculine men. They share makeup tips and dress styles to increase femininity, and with them, farther right talking points. Some also use this gender role to support a racist, pronatalist, illiberal politics that would deny women the vote in a new white nation state.

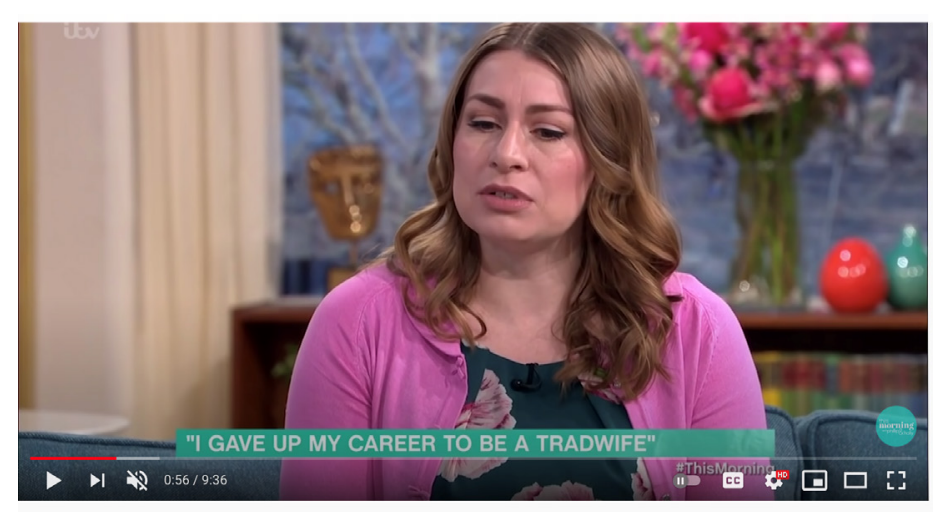

The Woman Who Would Rather Obey Her Husband Than a Boss | This Morning

Figure 4. Youtube archive of a morning tv show that celebrates the \#Tradwife movement

One of the strongest traditionalist and white identitarians is Lacey Lynn. In her video "Yes All Feminism" Lynn discredits feminism as an elitist movement, against white working men. She describes feminists as privileged, selfish, capitalist women, even though she locates the origin of the feminist movement in what she calls cultural marxism. Lynn suggests that the end of couverture laws, which granted us legal personhood, was actually feminists seeking money, status, and power over men. Her feminist origin story begins with an elite, wealthy and unfaithful woman who sued for divorce, "demanding property rights" and wanting money rather than fulfilling her own role of love and submission. This characterizes even early feminism and suffrage as selfish and capitalist, a concern only of elite women; even voting is attacking men and family. A Victorian divorce court becomes a metonym for all feminism. This is a narrative which would be very well known to participants in the manosphere, who often use divorce court as a symbol of the cultural dispossession and oppression of men. The right to divorce and the end of couverture laws, is framed by Lynn as women seeking to take from men, economically, without fulfilling their social role as submissive wives. Feminism from its inception, according to Lynn, has been about elite women exercising control over working class men.

Across the right, critiques of feminism use anti-capitalism in similar ways to discredit feminists as selfish, concerned only with money and not with family. Feminism is not about search for recognition, rights, or self but artificial elite social engineering, antithetical to women's fundamental nature as mothers. It's not something women needed, fought or starved for, but an elite game. This reflects our broader concerns about capitalist work, its lack of meaning or flexibility, but uses them in limited ways which reinforce gendered stereotypes. This is a familiar refrain in my own life, as my mother would also use economic arguments, asking me, why does feminism happen and all of a sudden you need two incomes to support a family? For some on the right, the answer is feminist marxist conspiracy.

\section{Feminists, Marxists and the Great Replacement}

While the language of anti-capitalism on the right speaks to real issues around supporting a family, it is undergirded, however, by a racist and misogynist politics linked to the conspiracy theory known as "the great replacement" or "white genocide." Hall explains that as multiple moral panics follow on another they become enjoined into a single grand conspiracy theory, here multiple panics around fertility, shifting gender roles and moral values, immigration, corporate capitalism and the tightening of the economy, become linked in a single grand theory of white genocide.

The great replacement, taken from the French author, Reynaud Camus, refers to a conspiracy by a shadowy network of elites to replace the culturally and racially rooted native-born White population with rootless, diverse, and more easily manipulable workers. This anti-immigration theory uses anti-elite and anti-capitalist language, but the heart is white men's replacement. As Holmes (2010) explains, this is a reaction against global capitalism and homogeneity, but the solution is "integralism" or the rebuilding of a racially, culturally unified people tied to a land. 
Its American iteration, white genocide, becomes more deeply tied into notions of fertility, purity, and antifeminism. White genocide states that elites are conspiring to end the white race through immigration, miscegenation, feminism, and indoctrination. Feminism and white women's political and economic participation is a "corporate capitalist" conspiracy to weaken the race by producing lower birthrates, a more submissive workforce, and a more left politics. White women who work, may pursue education and have children later, have fewer and spend less time raising them. Women's maternal nature means they will also be a more submissive workforce, more easily led by elites. Because of this submission, our suffrage will mean a welfare state and open borders. This is what white nationalist book The Turner Diaries describes as a nation like a nursery, padded and pink -- white women will be making a nation of weak babies instead of making more white babies.

White genocide was first promoted by the far-right but which has since been part of the Republican Party, as when representative Steve King suggested we "cannot restore our civilization with somebody else's babies." 3 As the tradwives and far-right women take up this theory they focus heavily on white women's need to make more children, and return to their roles as mothers, tying anti-feminism intimately to racism. We can see this in "Wife with a Purpose" Ayla Stewart's \#whitebabychallenge, which challenged other women like her to make as many white babies as possible.

We can see this growing emphasis on anti-feminism with two videos by the American Fascist Lana Lokteff and her Swedish husband Henrik Palmgren, shown in figure 5 below. In the first video around the great replacement, the global elites used economic crises to bring in immigrants. In the second, feminism and women's empowerment has become an essential part of the description.

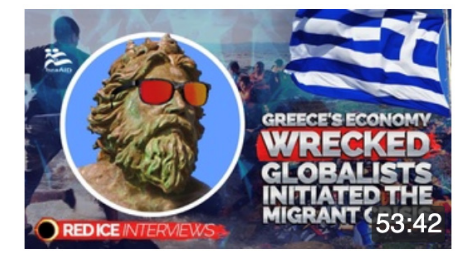

Greece's Economy Was Wrecked by Globalists to Initiate the Migrant Crisis - Poseidon

Red Ice TV

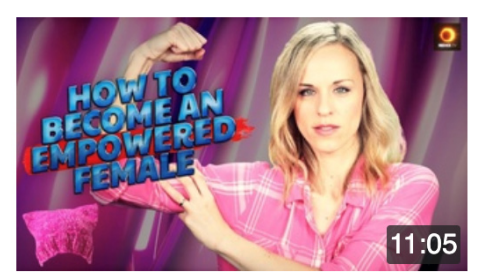

How To Become An Empowered Female

Red Ice TV

Even within this conspiracy theory, we can see a shift towards emphasis on gender politics. The Swedish video focuses on the white man's battle against shadowy cabal of Jewish cultural Marxist elites who are opening borders and attacking tradition. American white genocide offers a much more sexualized politics: a gendered version of replacement that blames white feminists for working instead of making as many white children as possible, dispossessing white men of their social and racial birthright. Their ambassador of cultural Marxism here is not a shadowy cabal but is often the empowered white female, Lacey's elitist suffragette, the professor "drinking until her ovaries dry up,4" who comes to stand in for all the corporate

Figure 5. Two vides from Red Ice TV illustrating the different takes on the

$$
\text { great replacement/white genocide conspiracy. }
$$

and cultural elite. In contrast to this elite, the ordinary working man is elevated as a rebel hero battling feminism for a return to breadwinner capitalism and the American way.

\section{The Redistribution of Sex}

The right presents economic and social change as dispossessing men of women, while the far right suggests this is leading to the end of the white race. We can also see this shift from economic to gendered dispossession in the gendered anti-capitalist language in the right's solutions to the current social crisis. The language of these solutions often blend the language of the market with the language of marriage, but offer state support for social not for economic power. Most famously, conservative Ross Douthat suggested a redistribution of sex.5 In his discussion of Incels and those men who are excluded from both dating and the labor market, he suggested a return to both traditional marriage and--failing that--the creation of sex robots.

While the idea was ridiculous, perhaps meant as a foil for his real call to return to patriarchal marriage, it was notable for both the heavy use of economic language and the absence of any real economic solutions. Douthat 
describes the current sexual moment as the result of the "Neoliberal deregulation" of the sexual marketplace which creates "new winners and losers." Sexual changes are linked to economic and technological change, celibacy and virginity are described as inequalities (of sexual access). He suggests we need "sexual redistribution" and compares Incels' lack of sexual access directly to those who suffer from economic deprivation.

A "pro-redistribution lobby" is not a lobby for a welfare state but for sex workers (or robots). These ideas are common on much of the far-right as well. Jordan Peterson often speaks about the need for social enforcement of patriarchy though monogamy, reframing the return to male dominance as a question of equitable sexual distribution. This is echoed by tradwives who celebrate patriarchy and pro-natalist politics, offering a vision of social and sexual success to alienated men.

This language of the sexual marketplace, which elevates men and demonizes feminists, is also common across much of the right. Sites like Reddit's Red Pill forum construct a kind of "sexual meritocracy" (Burnett 2021) that rates men's access to women, success dating or sleeping with them, in terms of his "sexual market value" or his "relationship market value." Women, as well, are encouraged to be submissive to raise their relationship market value or lose weight to improve their sexual value. On these forums, discussions of evolution and the survival of the hottest, also frame a lack of sexual success in terms of social inequalities and the oppression of men.

Blending this language in terms like sexual redistribution, deregulation of the marriage market shows a discursive slippage between economic and cultural dispossession, central to new discourses of white oppression across the right. Underneath the language of anti-capitalism is male supremacism. It is made desirable through discussions of sexual access and power. It's constructed through market language which naturalizes a transactional view of sexual relationships, making them "earned" or deserved on the market. Capitalist feminist deprive him of the natural result of this market success, social and economic dominance. The far-right call to reinforce this dominance with traditional marriage, rape gangs and "white sharia".

\section{So what?}

This essay explored how women mobilize anti-capitalist language to celebrate stay-at-home motherhood and advocate for a pre-feminist political and social order. They have taken on an increasing role in the movement, often framing themselves as warriors for the family and against the feminist. Feminists come to represent all of the failings of the late capitalist, liberal democracy as "symbolic glue," linking together varied right coalitions and interests and making these anti-feminist women's role ever more important. They use the language of workers' exploitation to paint liberal society as inherently against the family and women's true nature as mothers. This gendered reframing of critiques of late capitalism is elaborated in both the right's diagnosis of the problems of liberalism and its solutions: white genocide, or conspiracy theories which blame a feminist elite for low birthrates and social decline, and white sharia, the enforcement of the "redistribution of sex" and male power.

In her blog entry" Hey Grrrls you're not as irreplaceable as you think" Dissident Mama uses all these visions of freedom from corporate capital, embracing feminine roles and nature to characterize her own role within the movement:

Meanwhile, as my husband toils away at his occupation, sitting in a cubicle under fluorescent lighting, and dealing with all the insufferableness that can come with corporate culture, I'll be here, chilling in my yoga pants and tending to the "unpaid work" my sweet hubby subsidizes: homeschooling, full-time rearing of the kids, and blogging. Now there's some economic power, ladies.

Her writing here blends the critique of capital with a call to return to traditional gender roles which characterizes much of far-right discourse: the male sphere of work is framed as one of a "husband toiling" through bad lighting and insufferable culture while the home life is one of a "sweet hubby" who supports her raising three sons. Bloggers and organizers like Mama reframe traditionalism, it is not oppression but escape from it. It is not submission, it is a 
fight against our feminist elite.

This presentation of traditionalism as counterculture allows the right to appropriate critiques of capital while it exploits contradictions within mainstream right politics. As Hall explains, right wing movements map ideological contradictions between tradition and market onto gendered divisions of labor. Here, the contradictions between traditionalism and capitalism are neatly resolved by calling for women's return to the home. Capitalism squeezing families, reshaping traditional lives and values, even growing inequality and ecological collapse can be reframed in terms of "feminist attacks on the family" or "white genocide".

This discursive exploitation is effective because it calls to mind family and domesticity, or gender roles associated with family and love not extremist politics. It has become normal across the right; as Bjork-James notes this is common in evangelical families, while Briggs (2017) explains blaming feminism for capitalism's strain in the family happens across the Christian and mainstream right as well. The far-right's anti-feminism works because of broader American nostalgia for breadwinner capitalism; 74 percent of Americans, in a 2013 Pew survey, also believe women working has made it harder to raise children.

Their rightist vision of a return to postwar affluence happens through a return to the gender roles of this time - or earlier. Many far right men and women advocate for a vision out of the 1850's: the end of women's suffrage, economic participation or higher education. Lacey Lynn advocates "traditional courtship" meaning marriage out of high school, and couverture laws that would make women men's property. This nostalgic, normalized language of family against the corporate culture advocates for some truly extremist politics. The far-right uses the language of anti-capitalism, or anti-economic liberalism, in order to achieve political illiberalism - often by demonizing women's economic participation in order to advocate for our political exclusion.

Looking closely at this language matters. We might see the rise of populist language, resentment of elites, women calling for fewer bosses or the growth of parties like Neo-Nazi Matt Heimbach's "traditionalist workers party" as a rise in anti-capitalist sentiment. We might see Dissident Mama's critique of the \#resistance as corporate sponsored, and hope that we could win her support for a resistance that isn't sponsored by Nike, or which goes beyond a model giving a cop a Pepsi. But from Lacey Lynn to Dissident Mama, Tucker Carlson to JD Vance, this language of economic populism is directed at cultural elites.

Instead left scholars and activists might look more closely at how the economic language is used by the right to co-opt and reinterpret our experience of the failures of the economy. Their language promotes seeing the economy in gendered and raced ways; rather than simply trying to make appeals to their economic interests, or taking this anti-capitalist language as bad conscience or merely contradictory language, to look seriously at how economic life is invested with gender, racial and other social meanings. Only by looking seriously at what the right is doing, and how it is taken up and understood, can we begin to create alternative meanings and better futures. 


\section{Endnotes}

1. http://www.dissidentmama.net/disavowing-is-thedisgrace/

2. http://www.dissidentmama.net/public-schools-arekilling-our-kids/

3. https://edition.cnn.com/2017/03/13/politics/steveking-babies-tweet-cnntv/index.html
4. From Blonde in the Belly of the Beast, "My Redpill Journey" https://www.youtube.com/ watch?v=e8E3VjkSDqo

\section{References}

Bederman, Gail.1995. Manliness and Civilization: A cultural history of gender and race in the United States, 1880-1917. Chicago: University of Chicago Press.

Blee, Kathleen M. 2002. Inside organized racism: Women in the hate movement. Berkeley: Univ of California Press.

Burnett, S., 2021. “The Battle for "NoFap": Myths, Masculinity, and the Meaning of Masturbation Abstention". Men and Masculinities.

Dillingham, Rebecca. 2021. "Disavowing is the Disgrace" http://www.dissidentmama.net/disavowing-is-the-disgrace/ Accessed 5/30/21

Dillingham, Rebecca. 2019. "Public Schools are killing our kids"http://www.dissidentmama.net/publicschools-are-killing-our-kids/ Accessed 5/31/21

Dillingham, Rebecca. 2017. "Hey Grrrls" http://www. dissidentmama.net/hey-grrrls-youre-not-as-irreplaceable-as-you-think/. Accessed 6/1/21

Douthat, Ross, 2018. “The Redistribution of Sex. The New York Times. https://www.nytimes. com/2018/05/02/opinion/incels-sex-robots-redistribution.html accessed 5/30/21.

Du Mez, Kristin Kobes. 2020. Jesus and John Wayne: How White Evangelicals Corrupted a Faith and Fractured a Nation. New York: Liveright Publishing

Grebalzka, Weronika, Eszter Kováts, and Maari Põim. 2015. "Gender as symbolic glue." Luxemburg: Gesllschaftsanalyse und Linke Praxis. Breaking Feminism. 32-8.
Hall, Stuart. 1988. The Hard Road to Renewal. London: Verso.

Hargraves, Rebecca. 2017. "My redpill journey" https:// www.youtube.com/watch?v=e8E3VjkSDqo accessed 6/1/2021.

Holmes, Douglas R. 2010. Integral Europe: Fastcapitalism, multiculturalism, neofascism. Princeton: Princeton University Press..

Hoganson, Kristin L. 1998. Fighting for American manhood: How gender politics provoked the SpanishAmerican and Philippine-American wars. New Haven:Yale University Press.

Inoue, Miyako. 2004. "What does language remember?: Indexical inversion and the naturalized history of Japanese women." Journal of Linguistic Anthropology 14(1): 39-56.

Klemesrud, Judy. 1975. "Opponent of ERA confident of its defeat." New York Times. https://www.nytimes. com/1975/12/15/archives/opponent-of-era-confident-of-its-defeat.html Accessed June 1, 2021.

MacLean, Nancy. 2017. Democracy in chains: The deep history of the radical right's stealth plan for America. New York: Penguin.

Mattheis, A., 2018. "Shieldmaidens of whiteness:(Alt) maternalism and women recruiting for the far/altright". Journal for Deradicalization. 17:128-162. 
Pew Research Survey. 2013."Public Views on Changing Gender Roles"

Rosenthal, Lawrence. Empire of resentment: Populism's toxic embrace of nationalism. The New Press, 2020.

Schleifer, Theodore. 2017. "King doubles down on controversial 'babies' tweet. CNN.com https://edition. cnn.com/2017/03/13/politics/steve-king-babiestweet-cnntv/index.html. Accesed 5/30/2021.

Westermeyer, W.H., 2019. Back to America: Identity, political culture, and the Tea Party movement. Lincoln: U of Nebraska Press.

Whitehead, A.L. and Perry, S.L., 2020. Taking America Back for God: Christian Nationalism in the United States. Oxford: Oxford University Press. 